\title{
Spatial differences regarding the chance to leave supported public employment in Hungary's rural periphery
}

\author{
Tibor Kóti \\ University of Debrecen, \\ Hungary \\ E-mail: tiborkoti7@gmail.com
}

Time has passed since unified supported public employment was introduced in Hungary in 2011, thus enabling an analysis of the efficiency of the programme, using exact quantitative and qualitative methods. The present paper aims to comprehensively study the most significant employment policy measure in Hungary (supported public employment) with special regard to its efficiency. The paper studies the chances of integration with the open labour market, which is the open aim of supported public employment, in well-defined periphery areas. Based on qualitative analyses, the spatial structure of supported public employment, or the supported public employment rate, is presented with a situation in which public employees are supported in the labour market. This includes regional development's effects on peripheral areas and the budget's appropriateness. Based on quantitative analyses, it is discovered that one critical factor impeding integration into the open (alternative) labour market is atypical employment and its obstacles. Analysing the supported public employment programme's efficiency reveals a major issue in the high number of people in supported public employment, as the value of the lock-in indicator was higher than $80 \%$ in the 603 settlements studied in 2017. The present paper discusses the possible exposition of factors behind this lock-in, and its special cases have also been studied, (including age, gender, and qualifications). Supported public employment currently provides an opportunity to improve disadvantaged people's

Keywords: policy-related employment conditions by in-

lock-in creasing employment. This also includes straterural areas, integration, regional differences, gic rural, socio political, and regional development aspects. The study's national strategic role is reflected in that the conclusions drawn from

periphery areas, disadvantaged the data may illustrate a way to develop strategies to support public employment programmes with appropriate quality.

Regional Statistics, Vol. 8. No. 2. 2018: 109-134; DOI: 10.15196/RS080210 


\section{Introduction}

Supported public employment is a social and economic phenomenon first detected in ancient times, and can be defined as performing activities in the interest of the public, but with different contents in both space and time. Supported public employment was emphasized at times when labour market inequalities such as increasing unemployment, increasing poverty, and extended declassification, among others increased, and these could not be handled by active labour market mechanisms, such as enhancing the integration of disadvantaged groups unemployed through no fault of their own in the open labour market.

Marked regional differences exist in Hungary regarding employment (a west-east slope and core-periphery dichotomy) generating significant tensions, especially in marginalised areas. Studying labour market mechanisms in recent decades reveals that supported public employment is one of the most significant employment policies. Consequently, numerous works have been published in recent years on supported public employment, including its social and economic effects, primarily due to resolutions to improve employment (Csoba 2010a, Csoba 2010b, Messing 2012, Cseres-Gergely-Molnár 2014, Tésits-Alpek 2014a, Váradi 2016, Cirfusz 2015) However, most papers do not attempt to qualitatively and objectively expose and analyse the factors significantly hindering the programme's efficiency, which is an innovative element in the present research. The present paper's novelty is that it studies the open aim of supported public employment by analysing spatial processes, thus exposing the programme's most important inequalities.

Studying these processes on a spatial basis is relevant, as indicated by the fact that supported public employment as with labour market situations has changed significantly over the past decades. Employment policy trusts that a proportion of supported public employees will be employed in the competitive sector, however, companies have complained during labour shortages that relatively rigid supported public employment programmes have retained their potential labour force. This perspective reveals that increasing the minimum wage, especially compared to wages in supported public employment, may attract supported public employees to leave supported programmes. Unfortunately, supported public employment varies spatially. It is difficult to imagine that local economies in disadvantaged regions could generate jobs, especially when transitioning supported public employees into the labour market. In contrast, prosperous counties have few supported public employees, which is problematic given the employment capacity of the competitive sector in these areas.

The 2008 global economic crisis had a cumulative effect in Hungary, especially in its peripheral areas, due to disadvantages caused by marked differences in regional development. Previous empirical research has considered the exponentially disadvantageous situation in rural areas, in that the agricultural basis such as the reduction

Regional Statistics, Vol. 8. No. 2. 2018: 109-134; DOI: 10.15196/RS080210 
of processing plants or privatisation among other situations cannot be incorporated into long-term strategies. Thus, employees could not be mobilised towards other sectors (increasing their long-term unemployment) and supported public employment programmes, even if only theoretically, could contribute to the sustainability and diversification of the rural lifestyle (Farkas-Kovács 2018, Shucksmith 2010). The disadvantages of rural life are not the result of the crisis, but manifest as problems that have gone unsolved for decades due to uncertain working conditions, insufficient infrastructure and narrowing labour market mobilisation (PospechKulcsár 2016, Pospech et al. 2009).

The economic recession following the crisis substantially affected Hungary's labour market especially in rural areas. Many economic organisations became unstable; most could not manage the negative consequences of the crisis and they got out of records. Hungary had 477,351 registered job-seekers in 2008, which increased markedly and continuously to 604,576 in 2009. At a macro level, this increase caused economic deprivation. Consequently, the Hungarian employment policy aimed to reduce the high unemployment ratio with an open employment policy measure to escape the crisis namely supported public employment. The role of supported public employment became a field of improvement and as a result of this employment policy over the past 20 years ('Public Works': from 2000, 'Road to Work': from 2008 program, 'Unified Supported Public Employment': from 2011), the state's role has reduced. The priority has been to surmount the unemployment crisis by achieving a higher employment ratio, and to minimise passive state support by increasing jobs instead of aid.

Studying labour market tendencies in Hungary reveals the special role of supported public employment in employment growth as a whole, especially among disadvantaged groups and regions (Váradi 2016, Alpek et al. 2016). Currently supported public employment can be regarded as an important and innovative tool of regional development, as well as social and employment policies. Employment policy aims to improve labour market parameters and establish economic stability, thus improving Hungary's competitiveness. Regional development's role in realising supported public employment is reflected in its focus on regions suffering from depressed employment; it aims to reduce regional inequalities by focusing on deprivation in rural areas. An important aspect of the social policy involves eliminating poverty (pauperisation), and supported public employment seems to be an appropriate tool to realise this aim.

When supported public employment was first developed, its most important aim was to integrate or re-integrate participants into the open labour market as soon as possible. Certain studies indicate that both employers and supported public employees perceived potential re-integration rather pessimistically (Tésits-Alpek 2015, Tésits-Alpek 2017). Numerous government initiatives have been launched in recent years to aid integration or re-integration, although these risk disadvantage due to

Regional Statistics, Vol. 8. No. 2. 2018: 109-134; DOI: 10.15196/RS080210 
regional anomalies, such as the core periphery dichotomy which significantly affect open labour market conditions. This paper seeks answers by studying unified supported public employment to determine the actual probability of integrating supported public employment participants into the open labour market. The paper discusses the factors that impact supported public employment's efficiency, and outlines the probability that periphery areas will reach settlement levels by exposing regional differences. Further this paper aims to focus on the most underdeveloped regions in Hungary using an area delineation adjusted to a complex programme best conveying underdevelopment from a supported public employment perspective. Another aim involves studying the spatial structure of supported public employment, such as determining which regions are overrepresented in programme participation. Another noteworthy issue is the coherence of the support for settlements overrepresented in supported public employment given the particular region's unemployment rate. The present paper also describes the factors hindering integration into the open labour market by studying regional processes. Critical notes and complex recommendations are then provided after each factor has been discussed.

\section{Material and methods}

This paper's results are based on both primary and secondary methods. The research's primary aspect involves a complex visualisation of regional relations among the studied factors, with a special focus on inequalities. When analysing the regional aspects of supported public employment, the research highlighted Hungary's peripheral regions, especially from a supported public employment perspective, as well as such regions' chances of development. Settlement-level data were used, where available, for a more detailed analysis. However, regarding certain factors analysing supported public employment's efficiency, such as a study monitoring supported public employees, county- and country-level analyses were also important.

The present paper is based on the criteria widely used in international literature (Perger et al. 2016, Ray 1998, Dax 1996, Mardsen 1998). Thus, it grouped all settlements with population densities less than 120 people $/ \mathrm{km}^{2}$ based on 2011 census data into rural regions. Previously defined rural areas were also used as a basis for further delineation, with two additional categories: areas with population densities less than 60 people $/ \mathrm{km}^{2}$ are regarded as 'fundamentally rural' (2,145 settlements), while those with lower population density are regarded as 'mostly rural' (659 settlements). This further categorisation of already delineated rural areas was justified by the fact that supported public employment's efficiency, which is important relative to this paper, indicated clear differences in fundamentally and mostly rural areas. The present paper classified regions with population densities greater than 120 people $/ \mathrm{km}^{2}$ as 'urban' (350 settlements). Mapping urban and rural regions exposed Hungary's spatial inequalities regarding its core-periphery dichotomy.

Regional Statistics, Vol. 8. No. 2. 2018: 109-134; DOI: 10.15196/RS080210 
As these peripheral areas were delineated, factors could then be selected that characterise the most disadvantaged regions regarding supported public employment. Regions can then be identified based on the factors applied in the study in which the chances of leaving supported public employment have been minimised due to the regions' social and economic vulnerability. The factors' final selection was significantly influenced by the need for data sets that are reliable; controlled; easy to localise spatially; and complete, with data available for each settlement (Nemes Nagy 2009). In studying the relationships among these factors, Pearson's rank correlation justified including both factors, as they do not influence either each other or the current delineation. The following factors were used when peripheral regions were defined:

- The value of domestic migration per 1,000 inhabitants, $2016(\%)$,

- A lock-in indicator of supported public employment ${ }^{1}, 2016(\%)$,

- The average ratio of supported public employees among average working aged people, $2016(\%)$,

- The ratio of people with a maximum of eight classes of primary school qualification among supported public employees, 2016 (\%),

- The ratio of people aged 24 or younger among supported public employees, $2016(\%)$.

Data were then operationalised based on the supported public employees' place of residence and not their workplace location for each research factor. As the factors involved in the study were selected for the year 2016, this research did not aim to dynamically study these factors. It was important that certain factors be transformed into specific parameters, except for the lock-in indicator, to perform complex comparisons. Peripheral regions' supported public employment were identified using a normalisation method relative to the minimum-maximum interval:

$$
Z_{i}=\frac{X_{i}-X_{\min }}{X_{\max }-X_{\min }}
$$

where $Z_{i}$ is the normalised variable; $X_{\max }$ is the maximum value; $X_{i}$ is the studied data series; $X_{\min }$ is the minimum value.

The complex factor's value was determined by the arithmetic average of the normalised data series; values greater than the average (0.27) were categorised as peripheric. Moreover peripheric regions were further delineated to identify the most disadvantaged areas regarding supported public employment in the already identified rural areas. Strongly peripheric (494 settlements), fundamentally peripheric

\footnotetext{
${ }^{1}$ The Ministry of Interior constantly examines persons who entered some supported public employment programmes by considering whether the employee spent at least one year in supported public employment in the three years preceding their entry into the programme (continuity is not a condition). The calculation method used in the records from the National Tax and Customs Administration (tax return) determines the person's labour market status for several years. The lock-in indicator's value for settlements is the value compared to the average number of people and the number of supported public employees.
}

Regional Statistics, Vol. 8. No. 2. 2018: 109-134; DOI: 10.15196/RS080210 
(495 settlements) and mostly peripheric areas (510 settlements) were delineated using a one-to-three ratio. In studying supported public employment's efficiency, such as the factors impeding integration into the open labour market, fundamentally rural areas were regarded as standard and were grouped with various peripheral clusters; the present paper did not map characteristically rural areas due to previously mentioned reasons. A focus on fundamentally rural areas aims to highlight the chance disadvantages of rural regions, which contain mostly tiny villages with more marked labour market problems, even compared to characteristically rural areas, and with incredibly small chances of integrating into the competitive labour market (Bódi-Obádovics 2000).

The present paper primarily studies the specifics of changes following the introduction of unified, supported public employment (2011) to the current period (2017). This time period enables an adequate analysis of the experiences obtained from supported public employment and to draw conclusions regarding its efficiency and target orientation.

Secondary research primarily focuses on analysing and interpreting former scientists' works. In contrast, the primary research in this paper was based on comprehensive interviews conducted at the Ministry of Interior, Deputy State Secretary for Public Employment and Water Management over several time periods. This process obtained the actualities of supported public employment and experiences since its introduction, and future plans were discussed. The data used in this paper were requested from the Ministry of Interior's Strategy and Monitoring Department, and were analysed based on statistics from the Regional Development Information System (TeIR, http//www.teir.hu), the National Employment Service (NES, http//www.nfsz.munka.hu) and the Hungarian Central Statistical Office (HCSO, http//www.ksh.hu). Geoinformatic software, including Microsoft Excel and Quantum GIS Lisboa 2.18, were applied for data processing.

\section{Peripheral rural areas and supported public employment}

This study directly aimed to select indicators that delineate the most peripheric regions of supported public employment, and therefore, the social and economic backward indicators applied in former studies (Pénzes 2014, 2015; Faluvégi-Tipold 2012, Tóth-Nagy 2014, 105/2015. (IV.23.) Government Decree) were not used. Alternatively, periphery regions as delineated in the present paper strongly correlate with 'favoured regions' 2 as classified by the government.

Domestic migration per 1,000 people, whether temporary or permanent, suggests numerous factors, such as an insufficient infrastructure, slight labour market

2 105/2015. (IV. 23.) Government Decree: on the classification of beneficiary settlements and the criteria for classification.

Regional Statistics, Vol. 8. No. 2. 2018: 109-134; DOI: 10.15196/RS080210 
demand offers, and low-level education, among others. Therefore, this was selected as an important indicator of backwardness. According to our hypothesis, the higher the migration from a given settlement, the more significant the backwardness. The lock-in indicator, which will be discussed in further detail later, indicates certain regions' gradually increasing tendencies to integrate and re-integrate multiple disadvantaged supported public employees into the open labour market. As this parallels the primary aim of supported public employment in many cases, its incorporation among the indicators is justified. The high ratio of supported public employees among the working-age population suggests that regions' labour market inequalities are higher than average. Although supported labour market participation is overrepresented, stable participation in the open labour market is less likely, which can be explained by the disharmony between the labour market's demand and employment offering, in considering a lack of jobs to the high ratio of low- educated jobseekers that have been registered in the programme for a long time.

Indicators also include the ratio of supported public employees with a qualification of eight primary school classes. The act of leaving supported public employment is problematic in regions where this indicator is overrepresented, as low levels of education can possibly prevent employees from meeting the open labour market's demands, and employers typically do not rely on less-qualified supported public employees. Supported public employment is especially marginalised in regions where even young people or those under 24 years of age who are generally more mobile permanently participate in the programme. According to our hypothesis, the higher the number of supported public employees aged 24 or younger in a given settlement, the smaller the chance they will transition to the open labour market.

The long-term labour market recession in rural areas is proven by the fact that peripheral areas' supported public employment strongly correlates to fundamentally rural areas (see Figure 1); specifically, marginalised supported public employment is due to multiple factors in settlements with population densities of less than 60 people $/ \mathrm{km}^{2}$. Rural areas in the Southern Great Plains Region differ where periphery areas are scattered, such as Kecskemét and the agglomeration around Szeged.

Regional Statistics, Vol. 8. No. 2. 2018: 109-134; DOI: 10.15196/RS080210 
Figure 1

\section{Hungary's rural periphery regarding supported public employment, 2016}

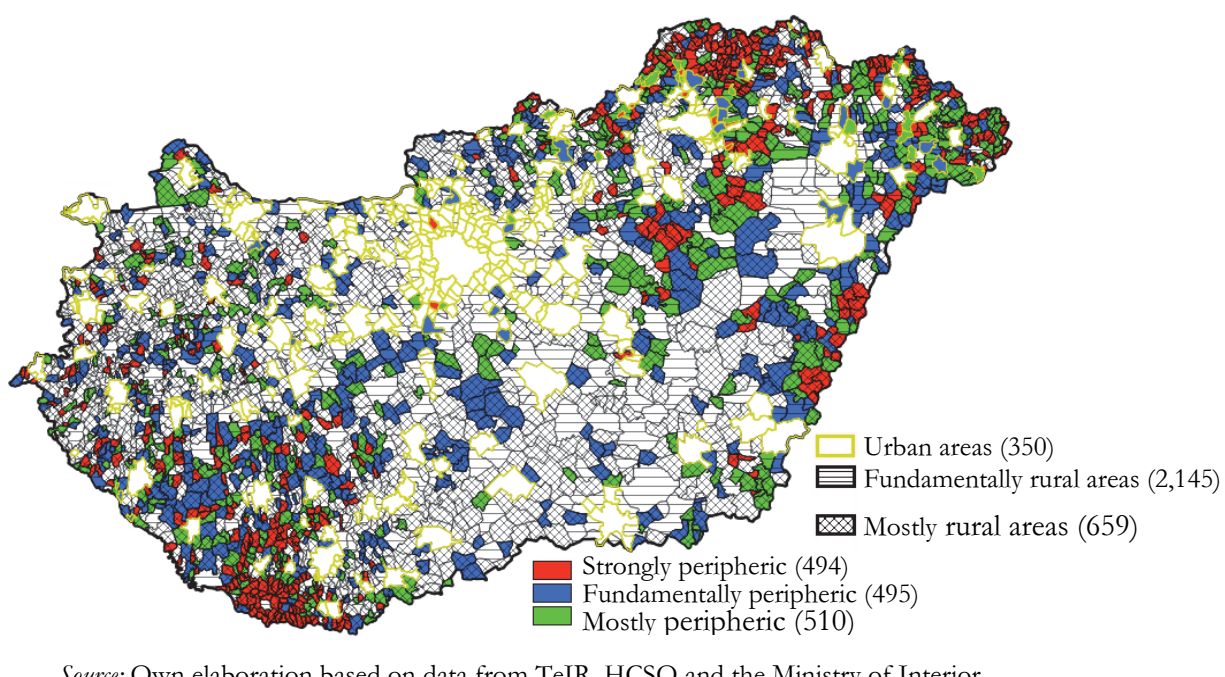

Strongly peripheric regions are found in two continuous zones: Baranya County, with its tiny villages, and in the micro-environment of Cserehát, in northeast Hungary. However, the outer peripheries of Szabolcs-Szatmár-Bereg and Hajdú Bihar in the southeast counties can also be classified here 3 . In contrast, fundamentally peripheric and mostly peripheric regions exhibit much greater spatial scattering, and mostly inner peripheral areas ${ }^{4}$ belong to these groups. While mostly eastern Hungarian counties can be highlighted in the former cluster, areas of backwardness can be found in the case of the latter, in several greater continuous zones in the Southern Transdanubian region, especially Somogy County, and scattered in Fejér County. Across the country, 430 settlements with approximately 192,000 inhabitants can be classified as strongly peripheric and fundamentally rural; 363 settlements with approximately 300,000 inhabitants are classified as fundamentally peripheric and fundamentally rural; and 395 settlements with approximately 400,000 inhabitants are grouped into the mostly peripheric and fundamentally rural regions.

In summary, it can be stated that peripheries identified from supported public employment point of view are regions with the most intensely depressive labour market where leaving the supported public employment programme is multiple problematic.

3 'Outer periphery regions' are areas along the border involving the country's most sensitive regions with multiple disadvantaged conditions, and even more backward places than in the inner peripheral regions (Baranyi 2004, Süli-Zakar 2009).

4 The 'inner periphery regions' are extensive areas in the inside regions of the country's interior, in which the consequences of the disadvantaged state occur in a higher than average concentration (Baranyi 2004, pp. 7).

Regional Statistics, Vol. 8. No. 2. 2018: 109-134; DOI: 10.15196/RS080210 


\section{The employment improving role of unified supported public employment}

Supported public employment has substantially changed since it gained importance around three decades ago to progressively influence labour market conditions over time. As a result of the significant economic recession from the 2008 economic crisis, the introduction of the 'Road to Work' programme was regarded novel, as it involved numerous innovations over former programmes. ${ }^{5}$ Its long-term measures and impact assessment aimed to improve employment, but could not be carried out, as the 2011 introduction of unified, supported public employment restructured the supported public employment system. This introduction can be regarded as one of the most significant employment policy decisions due to the change of government in 2010 .

The factors shaping the unified, supported public employment include the demotivating effects of passive state support ${ }^{6}$, short-term employment in supported public employment programmes, and a high level of unemployment ${ }^{7}$. Therefore, it was necessary to establish a complex system to reform all these factors. According to Kálmán (2015), such elements manifest as the macro-economic aims of supported public employment programmes, such as increased employment, direct job creation, fighting poverty, and a stimulation for the economy to create new jobs.

Hungarian employment policy had to transform to help integrate ${ }^{8}$ those people who lack the qualifications demanded by the private sector and who have had no employment activity for quite some time (Belügyminisztérium 2017). One important aspect of establishing unified, supported public employment involved identifying supporters. The programme offers those in backward situations, who have been unemployed for a long time, the chance to compete in the open domestic labour market; they can also return to this market to gain work competencies and experience job returns.

One key element of unified supported public employment is its value-creating supported public employment ${ }^{9}$, carried out in its framework of start-work programmes. According to Váradi $(2010,2016)$, these start-work programmes are currently critical employers in small, rural settlements, and are their only income source

\footnotetext{
5 The present paper does not aim for a detailed analysis, but Csoba (2010b) provides further detail.

${ }^{6}$ The state's welfare role prevented some people from entering the labour market.

7 The system was criticised because the typical three-to six month duration of public employment is insufficient to establish the 'existence' of employment for inactive people.

8 A primary aim involved helping those participating in public employment to succeed in the open labour market by developing their work routines, abilities and competencies (Public Employment Almanac 2011-2016).

9 Value-creating employment can be regarded as a programme type that employs the most people in both short- and long-term public employment. On average, 46,177 workers were employed in this programme in 2012, which increased to 84,953 workers in 2016 based on data from the Home Office.
}

Regional Statistics, Vol. 8. No. 2. 2018: 109-134; DOI: 10.15196/RS080210 
in numerous cases ${ }^{10}$; these programmes aim to establish value-creating supported public employment based on local conditions, which can then contribute to local economies and to possibly establishing local self-sufficiency. However, a different issue involves its sustainability, which creates dilemmas for local governments regarding cost efficiency, uncertain buyers, weather conditions, and seasonality, among other issues. Moreover, the goods production under the start-work framework provides only a temporary solution for most local governments, with slim chances of establishing permanent employment (Tésits-Alpek 2014b).

Significant unemployment has been successfully eliminated, as Hungary's unemployment rate was previously near the highest within the European Union according to Eurostat data (11.2\%). Currently (2017), Hungary has significantly decreased its level of unemployment (4.2\%). However, the reasons behind this higher employment reveal that supported public employment has played an extremely substantial role. Work conducted in the course of supported public employment would not be problematic on its own, but employment is only superficial in many programmes organised by most local governments. In the case of locally governed settlements with few inhabitants, the financial resources obtained through supported public employment are the most important sources of income, and therefore these settlements are not interested in eliminating this programme to integrate workers back into the labour market (László 2016). Further, supported public employment resources are unequally distributed in many cases, and do not parallel the unemployment rate (Cirfusz 2015). This indicates significant dilemmas regarding workers' integration into the open labour market, including the gradual reduction of those leaving the programme versus an increasing lock-in rate. Supported public employment has become an open tool for employment in peripheral regions, especially in areas comprised of smaller villages.

The ratio of supported public employment (see Figure 2) at the time unified, supported public employment was introduced in 2011 reveals a greater continuous zone of supported public employment dominance. This is especially notable from Vas-Hegyhát to Ormánság (Alsószenterzsébet - 74.7\%, Főnyed - 71.7\%) as well as in the Eastern Hungary border zone, especially in the regions of Cserehát (Regéc 40.9\%) and Szatmár-Tiszahát (Szatmárcseke - 34.5\%).

${ }^{10}$ Local governments primarily use goods produced in the start-work programme (such as public catering). Local governments also commonly give away these goods to indigent people as social benefits (Váradi 2016). The programme undoubtedly has the effect of extending employment.

Regional Statistics, Vol. 8. No. 2. 2018: 109-134; DOI: 10.15196/RS080210 
Spatial differences regarding the chance to leave supported public employment in Hungary's rural periphery

\section{Regional inequalities in Hungary's supported public employment rate*, 2011}

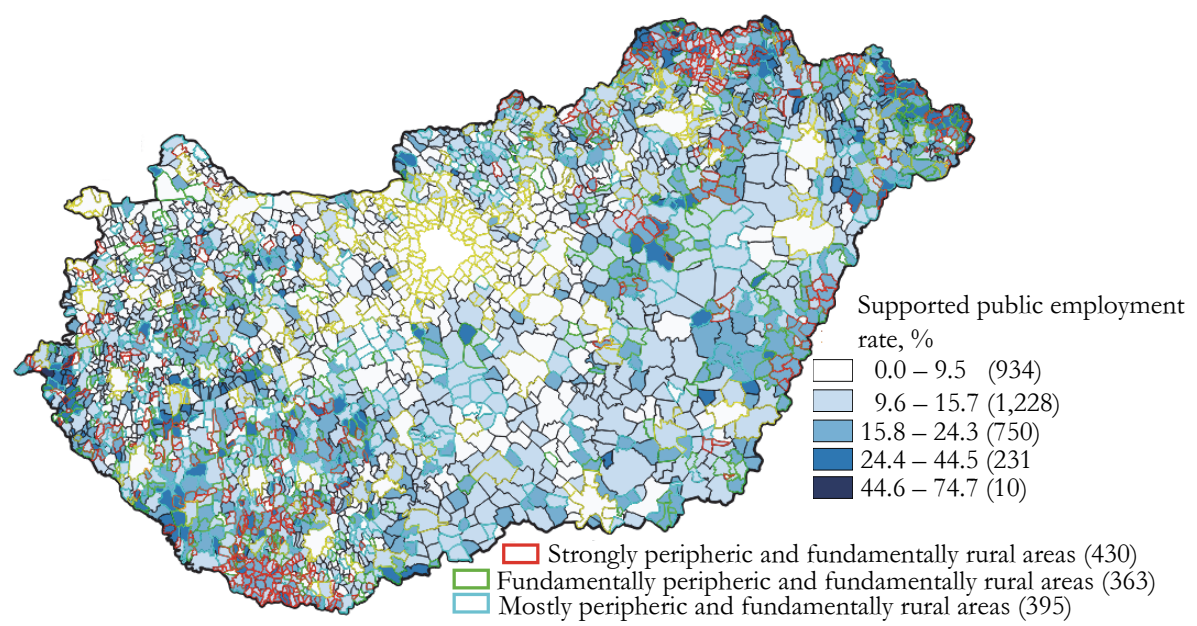

* The closing day number of supported public employees is compared to the closing day number of registered job-seekers.

Source: Own elaboration based on data from the Ministry of Interior.

Figure 3

\section{Regional inequalities of Hungary's ratio of supported} public employment, January-November, 2017

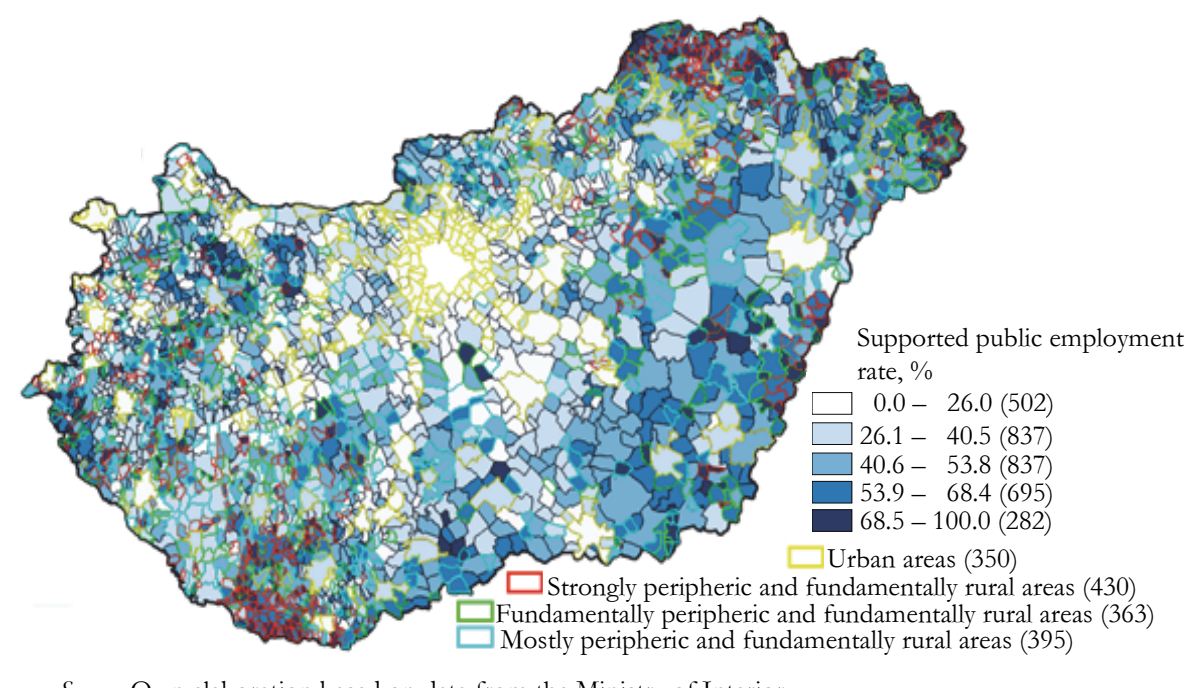

Source: Own elaboration based on data from the Ministry of Interior.

Regional Statistics, Vol. 8. No. 2. 2018: 109-134; DOI: 10.15196/RS080210 
Compared to conditions in 2011, the number of supported public employees significantly increased by 2017 (see Figure 3), partially as a result of the fact that the programme's financial resources had multiplied to achieve a greater volume of employment. The fact that supported public employment increases overall employment is indicated by the number of registered jobseekers in Hungary, or 582,900 people in 2011; this decreased to 285,500 people by 2017 . The spatial differences are significant at the macro-level, and were accumulated based on data from the National Employment Service. The 2017 supported public employment ratio was highest in Baranya (Ormánság), which has abundant rural areas, as well as Borsod-AbaújZemplén County (in the Cserehát region) and the outer peripheral regions of Szabolcs-Szatmár-Bereg County from Rétköz to Szatmár Plain.

The values among certain settlements further increased compared to 2011, including Regéc (75.7\%), Szatmárcseke (72.8\%), Tiszacsécse $(75.6 \%)$ and, Almáskeresztúr (92\%). Outer peripheral regions along the borders in Hungary especially along the border between Hungary and Ukraine, Hungary, and Croatia, and north-eastern Hungary and Slovakia are characterised by a lack of jobs. These regions' supported public employment includes any employment possibility and income source. The supported public employment programme's aim to increase employment there is reasonable, as these areas include an abundance of strongly peripheric and fundamentally rural regions.

However, one question involves how long supported public employment can decrease high unemployment in disadvantaged social groups living in rural areas. Clearly, if Hungary is to increase its competitiveness the labour market must be significantly restructured towards developing fields with high added value. Thus, support for training and job creation are essential due to their high lock-in ratios, to be discussed later. Although secondary employment undoubtedly and significantly improves employment figures, its sustainability and producing of value are not as obvious. If a greater volume of human resources are activated, for example, then employment restructuring can occur to shift employment from the supported labour market to the open labour market. Subsequently higher-quality individual lifestyles and a significant economic upswing could then be predicted, even in the rural periphery.

\section{Factors hindering integration into the open labour market}

This chapter discusses the factors that could significantly transition employment to the open labour market, although these factors are commonly characterised by their tendency to obstruct this transition. It is important to note that the factors to be discussed cannot independently solve the problems in this transition, as a qualified, skilled labour force is also required, which must be suitable for and motivated to enter competitive sectors throughout the labour market.

Regional Statistics, Vol. 8. No. 2. 2018: 109-134; DOI: 10.15196/RS080210 
Spatial differences regarding the chance to leave supported public employment in Hungary's rural periphery

\section{The lock-in indicator- and monitoring supported public employees}

The lock-in indicator is suitable to measure the probability workers will leave supported public employment. This measures whether an employee has spent more than one year in the programme over three years prior to entering supported public employment, and this time need not be continuous.

Figure 4

\section{Regional lock-in indicator inequalities in supported public employment, January-October 2017}

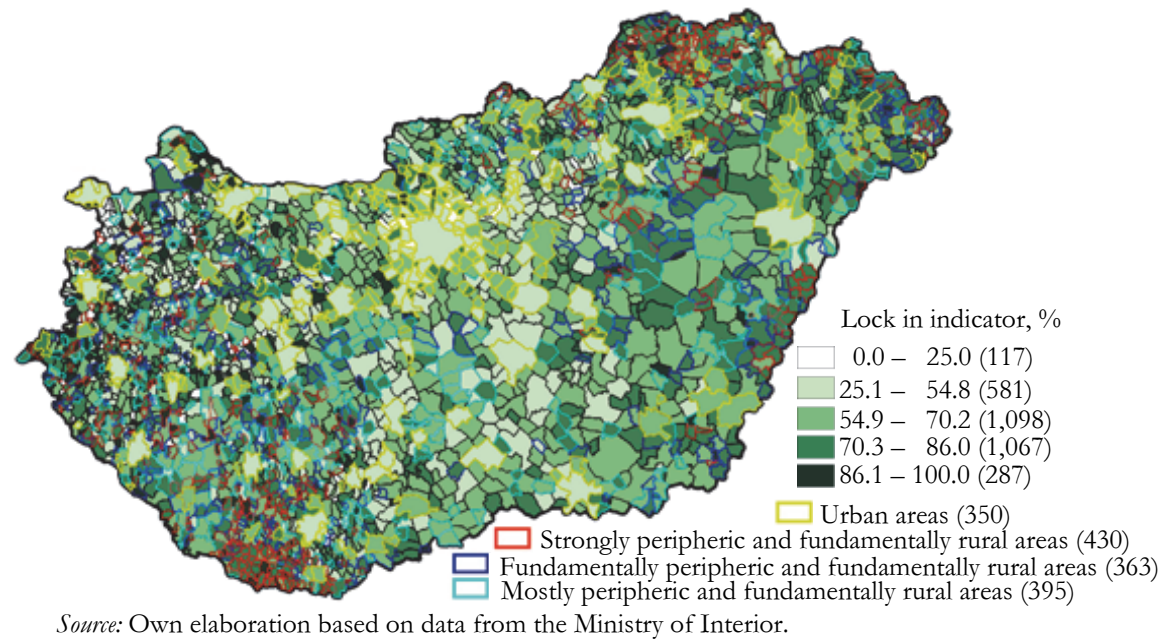

In supported public employment, the lock-in indicator is a specific, sensitive issue occurring at the macro-level; lock-in increased from 39.4\% in 2014 to $55.1 \%$ in 2016, and is still increasing. The indicator's heterogeneity is further demonstrated, in that no significant regional inequality can be observed (see Figure 4), and its spatial distribution is very even and does not only occur in typically strong peripheral regions. The highest values are found scattered in Western Transdanubia, and typically in its villages. A significant block of efficient supported public employment displays the value of the lock-in indicator as $100 \%$ at 151 settlements especially in fundamentally rural regions with low populations $80 \%$ at 603 settlements, and $60 \%$ at 2,196 settlements.

Gradually increasing the lock-in indicator is further amplified by the uncertainty factors of offers among the open labour market, as these incite supported public employees to remain in supported public employment. Uncertain downtime, possible commuting costs and time factors, higher expectations, minimal salary differences, most employers' prejudices and an individual lack of motivation do not compel employees to transition from supported public employment to the open labour market. The complex problems of a high lock-in ratio in the case of supported public em-

Regional Statistics, Vol. 8. No. 2. 2018: 109-134; DOI: 10.15196/RS080210 
ployment are explained by workers' probability of leaving the programme, which further decreases when considering the labour market's different spatial characteristics. These include: advancing atypical modes of employment in both settlements and regions, a lack of local supported public employment programmes, job-seekers' deficiencies included in these programmes, the programme organisers' personal and professional qualities and economic or political opposition among operators.

In the course of their study, Cseres-Gergely-Molnár (2014) concluded that the more time is spent in supported public employment the smaller the likelihood workers will leave the programme. This practically means that supported public employment traps most unemployed people and provides them no encouragement to leave (Váradi 2016). Further, Calmfors et al. (2002) consider that the lock-in in supported public employment can successfully decrease if job-creating programmes sufficiently imitate the real employment situation.

Quality professions obtained through certain supported public employment training programs - such as computer data recorder, security guard, electrician, or cook - may provide adequate work competencies that may also contribute to reducing employers' strong prejudice, and thus reducing the thus 'locking-in' of supported public employment in peripheral areas.

Another indicator suitable for determining the probability employees will leave public employment involves a study to monitor supported public employees after they have left supported public employment ${ }^{11}$ (see Figure 5). Tracking data reveals significant cumulative regional differences in this respect. Borsod-Abaúj-Zemplén County, Szabolcs-Szatmár Bereg County and third-ranked Hajdú-Bihar County are typical crisis areas. While $27 \%$ of those released from supported public employment returned to the former supported labour market during the studied period (2016), this ratio was 29\% in Szabolcs-Szatmár-Bereg County. The transition to the open labour market is relatively more positive for Borsod-Abaúj-Zemplén County $(14.5 \%)$, as this $2 \%$ higher than in Szabolcs-Szatmár-Bereg County (11.8\%). However, the ratio of those registered as unemployed is simultaneously much higher in Borsod-Abaúj-Zemplén County $(19.2 \%)$ than in Szabolcs-Szatmár-Bereg County $(13.2 \%)$. If the ratio is taken of those unsuccessful in the open labour market, the situation is problematic, as a high percentage of people leaving supported public employment did not appear on the open labour market at the time of the analysis. This includes $89.1 \%, 89.4 \%$, and $87.9 \%$ in Borsod-Abaúj-Zemplén, SzabolcsSzatmár-Bereg and Hajdú-Bihar Counties, respectively, which includes those of unknown. In summary, the ratio of those appearing on the open labour market is very small in all studied counties, and even outside the highlighted regions.

11 This method essentially operationalises the individual's labour market status on the 180th day after leaving public employment. This tracking analysis reveals whether the previously supported public employee appears on the open labour market, or again on the supported labour market, or possibly among those who are registered as unemployed.

Regional Statistics, Vol. 8. No. 2. 2018: 109-134; DOI: 10.15196/RS080210 
Figure 5

Ratio of people leaving supported public employment programmes according to their labour market status on the $\mathbf{1 8 0}^{\text {th }}$ day from their release from the programme in different counties, 2016

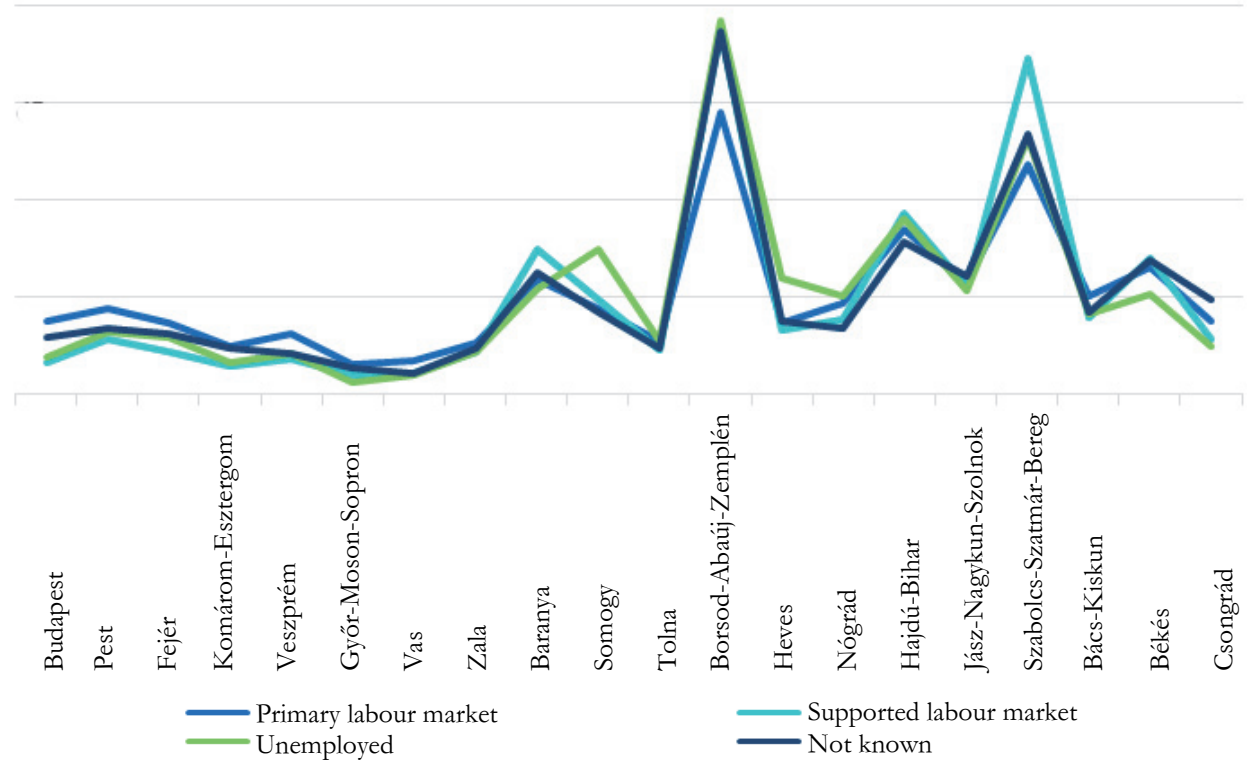

Source: Own calculation based on data from the Ministry of Interior.

It is noteworthy that some special cases include people who also 'stick to' supported public employment based on their gender, age, or other qualification. Further, no significant difference can be observed regarding the gender distribution of those reappearing in the supported labour market (women: 58.8\%, men: 54.5\%). The same applies to those appearing as unemployed status, in which the difference is only $0.9 \%$ for men.

The labour market situation for people younger than 25 years of age - an indicator of which is also used in delineating peripheral regions - reveals a much more concerning image. In the studied time period, $63.7 \%$ of supported public employees in the given age group did not appear on the open labour market, which can also explained by major social (negative examples from parents) and economic (a lack of jobs or employers' prejudice) problems.

Thus, and as anticipated, the highest lock-in ratios are found among those supported public employees with primary school as their highest education; of this group, $56.6 \%$ reappeared on the supported labour market. It is further unanticipated

Regional Statistics, Vol. 8. No. 2. 2018: 109-134; DOI: 10.15196/RS080210 
that $57.2 \%$ and $43 \%$ of those with secondary education or higher, and typically education from nationally supported public employment programmes, respectively, also reappeared on the supported labour market in the studied period.

It is noteworthy that the present study includes only one year (2016) in which no dynamic data series are analysed. However, the above macro-level lock-in values are of concern, as the dynamic data (2014-2017) of certain rural peripheral areas (specifically, the Baktalórántháza district) exhibit a significant increase from $44.7 \%$ to $65.3 \%$ (Jász et al. 2018). Nevertheless, the success of supported public employment is measured not only by workers' integration and reintegration into the open labour market. Significant results, especially in rural peripheral areas, include: improving potential employees' suitability for competitive sectors throughout the labour market, parallel training for supported public employees; producing values targeting settlements' development; and providing temporary support to these workers.

\section{Regional development's effects on the labour market in rural peripheral areas}

Hungary's labour market cannot be handled as a homogeneous 'mass' at either the macro- or micro-levels. Joining the European Union (2004) has extended its regional development possibilities, although regional development differences are still significant, regarding in our case of the labour market. Moreover, regional development primarily aims to impede backward regions' fragility and falling further behind while eliminating chance social and economic disadvantages. Significant effort has been made across numerous regions in Hungary to fight the labour market's depression, including north-eastern Hungary, southern Transdanubia, and, especially, Baranya County. Thus, labour market anomalies are especially important in shaping core and periphery regions (Government Decree 105, 2015). Despite this, hardly any significant social and economic development can be detected outside regional and county centres, which delineates insignificant job-creation investments. To study the development and backward state of Hungary's labour market, it is noteworthy to analyse the number of vacant jobs (see the Table), which is the most suitable indicator to predict the development potential in a given region's labour market.

The number of vacant jobs in the studied periods was smallest during the 2011 labour market recession in almost all counties, which can be explained by the effects of the economic crisis. It is noteworthy that the highest number of vacant jobs was found in Borsod-Abaúj-Zemplén County, which has been marginalised from several perspectives; it has an abundance of tiny villages and a high Roma population ratio, among other factors. Further, the county has the highest number of registered jobseekers, suggesting that a significant amount of human capital either cannot meet or only barely meets the labour market's requirements. As a result of the economic development in recent years, in which job offers have been increasingly extended, the number of vacant jobs increased in 2017 (13,764 people), but significant inactiv-

Regional Statistics, Vol. 8. No. 2. 2018: 109-134; DOI: 10.15196/RS080210 
ity still exists $(37,420$ people). Similar tendencies are also found in both SzabolcsSzatmár-Bereg and Hajdú-Bihar County compared to the total population. A question has also arisen regarding the high number of vacant jobs, in that so many people remain in supported public employment despite jobs' availability. The highly incongruent relationship between vacant jobs and registered job-seekers suggests that no long-term strategies are based on the human capital in such regions as they either pertain to foreign investments or involve high risk especially in BorsodAbaúj-Zemplén, Szabolcs-Szatmár-Bereg, Hajdú-Bihar, and Baranya counties, and most strikingly in Jász-Nagykun-Szolnok County. Balcsók (2000) conducted similar research along Hungary's north-eastern border to conclude that a high proportion of unemployed people in the region are associated with the Roma ethnic group, the economically active aged members of which are mostly undereducated. Unfortunately, the saying that 'who wants to work will find a job' is not always true (Balcsók 2000). This is a social feature that can also be detected in the present day. In summary, although many vacant jobs exist, the skilled labour they require is missing.

\section{Number of vacant jobs in Hungarian counties and in Budapest, considering the vacant jobs getting out of registration and the number of registered jobseekers, $1,000 \mathrm{pc}$}

\begin{tabular}{|c|c|c|c|c|c|c|c|c|c|}
\hline \multirow{2}{*}{ County } & \multicolumn{3}{|c|}{2011} & \multicolumn{3}{|c|}{2014} & \multicolumn{3}{|c|}{2017} \\
\hline & $A^{\text {a) }}$ & $\mathrm{B}^{\mathrm{b})}$ & C) & A & B & $\mathrm{C}$ & A & B & $\mathrm{C}$ \\
\hline Budapest & 6,993 & 3,344 & 48,750 & 23,854 & 7,499 & 3,6078 & 30,738 & 6,284 & 19,755 \\
\hline Pest & 4,096 & 836 & 41,719 & 10,251 & 2,775 & 3,4328 & 8,542 & 2,321 & 22,941 \\
\hline Fejér & 2,562 & 1,274 & 22,903 & 5,523 & 2,194 & 1,4598 & 4,128 & 1,455 & 8,977 \\
\hline Komárom-Esztergom & 2,686 & 1,278 & 13,920 & 4,046 & 2,121 & $, 8,962$ & 3,311 & 1,495 & 5,303 \\
\hline Veszprém & 2,270 & 1,396 & 17,472 & 4,065 & 2,144 & 1,0890 & 3,508 & 1,372 & 6,420 \\
\hline Győr- Moson-Sopron & 3,325 & 1,835 & 11,957 & 4,606 & 2,188 & 5,859 & 5,868 & 2,100 & 3,410 \\
\hline Vas & 2,082 & 1,019 & 8,903 & 3,671 & 1,387 & 6,021 & 3,135 & 1,035 & 4,339 \\
\hline Zala & 3,599 & 2,051 & 15,772 & 4,647 & 2,183 & 1,2262 & 4,877 & 1,755 & 7,371 \\
\hline Baranya & 3,112 & 1,780 & 29,213 & 5,5 & 3,340 & 2,03 & 5,601 & 3,176 & 14,296 \\
\hline on & 2,8 & & 25,4 & 3,729 & 2,461 & 2,01 & 3,350 & 1,815 & 14,838 \\
\hline Tolna & 1,849 & 1,084 & 14,470 & 2,013 & 1,270 & 1,0423 & 1,880 & ,914 & 6,853 \\
\hline Borsod-Abaúj-Zemplén & 10,890 & 5,369 & 69,393 & 15,623 & 9,259 & 5,1430 & 13,764 & 7,120 & 37,420 \\
\hline Heves & 2,520 & 1,632 & 21,361 & 3,944 & 2,545 & 1,4816 & 3,940 & 1,759 & 11,739 \\
\hline Nógrád & 2,829 & 1,416 & 19,945 & 3,446 & 1,923 & 1,4841 & 4,514 & 1,641 & 11,534 \\
\hline Hajdú-Bihar & 7,008 & 3,210 & 47,151 & 12,874 & 5,652 & 3,6917 & 10,450 & 4,042 & 25,305 \\
\hline Jász-Nagy & 4,697 & 2,259 & 30,294 & 9,288 & 5,149 & 2,1618 & 12,402 & 5,991 & 15,693 \\
\hline Szabo & 9,710 & 4,890 & 61,010 & 13,765 & 7,290 & 4,5840 & 7,051 & 2,553 & 31,287 \\
\hline Bács-Kiskun & 4,675 & & 33,639 & & 3,440 & 2,45 & & 2,936 & 15,011 \\
\hline Békés & 4,576 & 2,653 & 27,782 & 6,130 & 4,258 & 1,7574 & 5,997 & 2,963 & 11,727 \\
\hline Csongrád & 3,411 & 1,948 & 21,766 & 5,155 & 2,944 & 1,4915 & 4,104 & 2,256 & 8,751 \\
\hline Total & 85,736 & 44,610 & 582,872 & 147,466 & 72,022 & 422,446 & 143,228 & 54,983 & 282,970 \\
\hline
\end{tabular}

a) A Monthly average number of registered vacant jobs. b) B Monthly average number of vacant jobs getting out of registration. c) C Monthly average number of registered jobseekers.

Source: Own editing based on data from NES (2018).

Regional Statistics, Vol. 8. No. 2. 2018: 109-134; DOI: 10.15196/RS080210 
Pénzes (2011) also explains rural areas' backwardness, with a complex, problematic group of low-income earners that foreshadows the given area's marginalised economic potential, as consumption is also low in these regions and supports a smaller number of companies. This also results in increasing social costs and permanently low-level labour market offers (Pénzes 2011).

The lack of jobs also means that the transition from supported public employment to the open labour market will create dilemmas. The passivity of economically active disadvantaged people beyond their own fault is explained by the highest number of vacant jobs and vacant jobs getting out of registration are the lowest in the peripheral regions hit by the labour market depression, with the present case focusing on north-eastern Hungary. Thus, the chance of leaving supported public employment is minimal, especially for people with a non-skilled education. Future regional development must prioritise the creation of jobs in peripheral regions. Until this tendency changes, restructuring the population's employment will be an 'unfamiliar' definition among settlements further away from the nation's centre. To realise abundant job creation the development of human resources to determine present competitiveness is inevitable, especially in the highlighted 'backwards' regions. A high number of successful local developments are required to create labour market momentum among Hungary's peripheral areas, which will provide long-term, sustainable living for those in rural areas.

\section{Spatial allocation of the budget aimed for supported public employment}

The following section considers regional inequalities in the budget aiming to support public employment as well as the ratio of registered job-seekers. The programme's budget indicates a significant time dynamism - as previously mentioned as payments have multiplied since unified supported public employment was introduced (2011: 72.5 billion forints). In 2016, 267.63 billion forints were allocated for various supported public employment programmes, including national, long-term, and district start-work programmes).

As anticipated, the spatial distribution of most registered job-seekers (see Figure 6) indicates a significant synergy with strongly peripheric and fundamentally rural regions, and particularly in Southern Transdanubia, located in northern Hungary. An exception is the Central Tisza region, where many economically inactive people were registered, but this region cannot be classified as strongly peripheric in its supported public employment. Numerous settlements have critical values: 'full' unemployment $(100 \%)$ can be observed only in Tornakápolna, although several other settlements exhibit significantly depressed labour markets: Csenyéte $(90.9 \%)$, Lasztonya (81.8\%), Endrefalva (76.7\%), Rinyabesenyő (62.6\%), Abaújszolnok $(61.7 \%)$, and Tiszabura (55.5\%). A common characteristic among the affected regions is that working-aged people are permanently missing from the open labour market.

Regional Statistics, Vol. 8. No. 2. 2018: 109-134; DOI: 10.15196/RS080210 
Figure 6

Regional inequalities of payments for supported public employment and the ratio of registered job-seekers within the working-age population, 2016

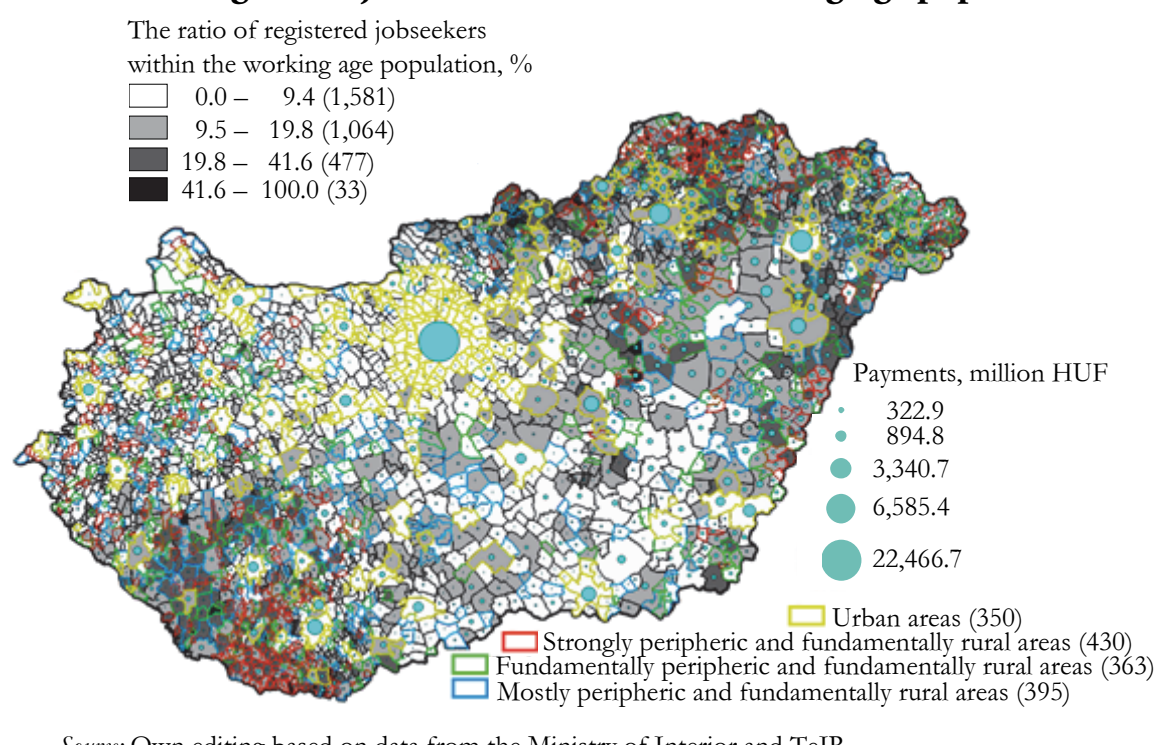

Regarding supported public employment, a significant eastern Hungarian dominance can be observed. Settlements receiving high support separate from county centres - as this support in such a volume is causeless (more favourable settlement geographical features) in many cases - include: Gyula (1.95 billion HUF), Ózd (1.85 billion HUF), Hajdúböszörmény (1.61 billion HUF), Baja (1.51 billion HUF), Püspökladány (1 billion HUF), Hajdúhadház and Hajdúnánás (895 million HUF), Kisvárda (882.6 million HUF), and Hódmezővásárhely (823.3 million HUF), Western Hungary's county centres are mostly supported in greater volume; this contrasts Eastern Hungary, where greater support exists for both the inner and outer peripheral regions.

This work then studies inequalities among registered job-seekers and supported public employment assistance (Hoover index). Regarding the distribution of financial resources when comparing registered job-seekers and the working-age population, significant regional differences can be detected in the strongly peripheric and fundamentally rural $(42.2 \%)$, the fundamentally peripheric and fundamentally rural $(44.3 \%)$ and the mostly peripheric and fundamentally rural (41.4\%) regions. Significant anomalies can be found in all the studied clusters, as it would be necessary to re-allocate more than $40 \%$ of financial resources to balance the previously men-

Regional Statistics, Vol. 8. No. 2. 2018: 109-134; DOI: 10.15196/RS080210 
tioned differences ${ }^{12}$. Aside from the studied clusters, significant differences can also be observed at macro level, as the Hoover index's value is $54.7 \%$. This is concerning when regarding target orientation; if a majority of the resources are not concentrated in regions with the highest unemployment rates, then this decreases workers' chance of leaving supported public employment. Subsequently, employees from social groups living at the given settlement will be permanently barred from real work. Chance disadvantages multiply in regions with smaller villages, or those with populations of less than 200 people, in which the Hoover index is $42.5 \%$. As a result of an underdeveloped infrastructure and a lack of economic institutions, supported public employment is presented as a primary priority, although this cannot be provided for every inactive person. The situation is slightly better for settlements with populations of 200 to 500 and 500 to 2,000 people. Re-allocations of $35.5 \%$ and $34.6 \%$ would be required in the former and the latter, respectively, to reduce differences and improve employment.

Hungary's social and economic isolation would greatly improve if an open labour market integration was more successful; thus, financial resources from the must decrease to achieve this, as these resources would also contribute to dissolving the country's 'rigid' spatial structure.

\section{Alternative labour market - atypical employment}

One of the most significant factors hindering employment strategies' success involves the advance of alternative labour market norms, especially among those living in small, disadvantaged settlements. Currently, the number of companies conducting illegal employment practices - or simplified employment, in a better case is growing. Finding such (illegal) employment creates major dilemmas, as even local governments in many cases are not interested in blocking such habits. 'Day labouring' is one of the most widespread alternative jobs for disadvantaged, inactive jobseekers, and is considered even traditional. If this were eliminated, it would contribute to the spreading of pauperisation and extreme poverty, and thus, local governments have attempted to compromise with different economic organisations. The following portion of this work analyses the effects of supported public employment and atypical employment synergies blocking integration to the open labour market.

It is widely known that supported public employees, and typically those in rural regions, take 'second jobs' to increase their income. Most of these second jobs are illegal, which opposes the entire system and aims of supported public employment. In such cases, supported public employees augment their salaries from supported public employment with income obtained through atypical employment, or typically

12 Such re-allocation of support for public employment would be required for equalisation, and to allocate support to the levels of registered job-seekers.

Regional Statistics, Vol. 8. No. 2. 2018: 109-134; DOI: 10.15196/RS080210 
day-labouring, which includes simplified employment and hired labour. This alone would not be such a substantial problem, as this is the only way to fight poverty. The problem is that supported public employment and atypical employment do not collectively motivate workers' appearance in the open labour market; this is partially because their joint income is greater than the income from one proper job.

The Roma people primarily conduct seasonal work in their supported public employment. For a long time, the law blocked jointly supported public and seasonal employment, resulting in significant tensions as seasonal employment during times of congested agricultural tasks has provided a source of income for centuries to (mostly Roma) people living in rural areas. Current laws provide opportunities for those involved in supported public employment to also take on seasonal employment, although such workers sometimes rush from one 'workplace' to the other by frequently cutting off the first occupation's work hours (Kóti 2016).

According to Messing (2012), in the case of greater settlements with more complicated demand-offer relationships, organising institutes do not adjust to the seasonal labour market. Employees must then choose between seasonal work, which provides higher income but high uncertainty and seasonality, and supported public employment, which provides a more secure source of income for most of the year, but is also unpredictable at times. Unfortunately, this presents problems that have remained unsolved for decades among smaller settlements; its primary consequence is that it absorbs labourers from the open labour market (Messing 2012). However, Váradi's (2016) research results prove that supported public employment organisers attempt to meet the labour demands of numerous settlements' economic organisations while adjusting to the requirements of the alternative labour market, even by completely ignoring the bureaucracy: 'Law has changed so that if the farmer requests it, the labour office sends supported public employees for him for "day labour" upon his recommendation. The labour office practically said that this should not be made complex administratively. Consequently, I invited the farmers for a talk and told them that it is better for all of us if we handle things [internally].' (Váradi 2016, pp. 47). Local government leaders have multiple underlying reasons keep workers in the supported public employment system, as it is impossible to live on benefits alone. Thus, the local government's burden would be eased if people took on 'second jobs' even informally, as fewer benefits would then have to be paid. Companies in the affected regions are also interested in sustaining atypical employment in an informal framework to avoid their tax load, and they have made no efforts to widen such employment (Vida-Virág 2010).

In summary, it can be stated that the alternative labour market and atypical employment act in opposition to the aims of the system. Its elimination and hindrance, however, are not even in the government's interests; for example, one of the most important elements in the European Union's 2020 professional strategy involves fighting to decrease the number of people living in poverty. This is because atypical

Regional Statistics, Vol. 8. No. 2. 2018: 109-134; DOI: 10.15196/RS080210 
employment, on the one hand, seems to be one of the most important perspectives in fighting poverty in rural marginalised regions. On the other hand, we must recognise that the issue a critical factor hindering the appearance of supported public employees in the open labour market.

\section{Conclusions}

This paper primarily aimed to outline the efficiency of supported public employment in Hungary's rural peripheral regions and the programme's compliance with its primary objectives. Supported public employment is frequently the only labour market option for social groups living in rural areas, especially those that are disadvantaged, and it is Hungary's most significant employment policy tool. Therefore, an important question remains regarding how this programme can be sustainable in rural peripheral regions in the long term, although this the most important aims of the programme itself.

Based on the research results from analysing the efficiency of supported public employment, the following conclusions can be drawn:

- A strong labour market recession occurred due to the economic crisis, with the number of registered job-seekers in Hungary (477,351 in 2008) gradually declining to the current number (243,498 in 2016). The supported labour market has undoubtedly created positive employment effects, as the number of registered job-seekers decreased to a minimum and several thousands of people became active again.

- In studying supported public employment's efficiency, it is important to mention that many supported public employees cannot or can hardly integrate into the open labour market due to changed work abilities or illiteracy, among other factors.

- Strongly peripheric and fundamentally rural regions identified relative to their supported public employment (430 settlements in Hungary nationwide) are the most sensitive areas, with a depressed labour market in which workers' transition to the open labour market is the most fragile. Regions classified under this cluster exist at the utmost reaches of the periphery - especially Ormánság, Cserehát, the Rétköz- Szatmár Plain, and their microenvironments - and contribute significantly to high lock-in indicator values in supported public employment.

- The lock-in regarding the supported public employment programme is problematic at macro levels as the lock-in indicator's value is greater than $80 \%$ in 603 studied settlements. Greater regional differences cannot be detected (i.e. scattered areas in the Western and Central Transdanubia regions have smaller villages that exhibit incredibly high ratios). Further, strongly peripheric regions are overrepresented in their lock-in indicator values.

Regional Statistics, Vol. 8. No. 2. 2018: 109-134; DOI: 10.15196/RS080210 
- Lock-in indicators for supported public employees (monitoring analysis) demonstrated a significant deprivation in three counties, in which the efficiency of the transition from supported public employment is a major hindrance to supported public employees appearing on the open labour market. In Borsod-Abaúj-Zemplén, Szabolcs-Szatmár-Bereg, and Hajdú-Bihar counties, $89.1 \%, 89.4 \%$, and $87 \%$ of supported public employees leaving supported public employment did not appear on the open labour market in the studied period, respectively.

- The incongruent relationship between the number of vacancies and registered job-seekers can be interpreted as an exogenous factor slightly reducing the lock-in. The lack of jobs foreshadows the fact that the transition from supported public employment to the open labour market raises significant dilemmas, especially in the previously discussed regions. Thus, regional policy must pay greater attention to creating jobs in peripheral regions.

- The vast majority of financial resources for supported public employment are concentrated in eastern Hungary, which is remarkable given the reduced regional differences, such as along the west-east slope. However, its relationship with the number of registered job-seekers indicates significant regional inequalities based on the Hoover index, which scored $54.7 \%$ on the macro level. Therefore, re-allocating this financial resources ratio nationwide would be necessary to balance regional differences and allocate resources that more closely parallel the number of registered job-seekers within the working-age population.

- Taking on supported public and atypical employment also does not seem to encourage employees to leave the programme, as the higher income obtained in this way discourages them from appearing in the open labour market.

Thus, the programme has achieved partial success and target orientation in accordance with its primary objectives. It could be interesting to investigate the role of the open labour market's willingness towards employment as a factor contributing to the growing lock-in ratio for supported public employment, a topic not among the present paper's goals. Our basic hypothesis is that lock-in for supported public employment especially in strongly peripheric, fundamentally rural regions is increases the most because of the prejudiced attitudes of employers, which hinders workers' natural transition. However, this can generate positive effects, such as long-term strategies to integrate the open labour market when supported public employment training considers territorial aspects to self-organise to meet employers' expectations and needs (human resource development). Thus, continuous and preventive labour market surveys could enable disadvantaged workers to acquire quality certifications and have an actual opportunity to quit the programme. Incidentally, this process could play a prominent role in reducing labour shortages in each area.

Regional Statistics, Vol. 8. No. 2. 2018: 109-134; DOI: 10.15196/RS080210 
Active labour market instruments have a long history, both internationally and in Hungary. These can be defined as the policy methods often used even today, primarily in liquidating long-term unemployment. Further, they raise an important question regarding how active political interventions can be realised - at different international levels as well as among similar program types - to achieve greater efficiency. This research left this topic to future studies because of the extensive study required, which is outside of the scope of the current work.

Alternatively, it is important to declare that supported public employment as a whole has a critical function in regional and social policy development. Peripheral areas delineated based on supported public employment may provide a tool for specific policies' greater success in their target orientation and efficiency. Supported public employment is a primary tool for multiple disadvantaged social groups living in Hungary's rural regions to fight both marginalisation and poverty.

\section{REFERENCES}

AlPEK, L. B.-TÉsITS, R.-BOKOR, L. (2016): Group-specific analysis of commuting in the most disadvantaged areas of Hungary Regional Satistics 6 (1): 54-81. https://doi.org/10.15196/RS06104

BALCSÓK, I. (2000): Hátrányos helyzetű társadalmi rétegek az Északkelet- Alföld határ menti térségeinek munkaerő-piacán Tér és Társadalom 14 (2-3): 285-294. https://doi.org/10.17649/TET.14.2-3.596

BARANYI, B. (2004): Gondolatok a perifériaképződés történeti előzményeiről és következményiről Tér és Társadalom 18 (2): 1-21. https://doi.org/10.17649/TET.18.2.942

BELÜGYMINISZTÉRIUM (2017): Köそfoglalkoztatási statisqtikai évkönyv 2011-2016 Budapest.

BÓDI, F.-OBÁDOviCS, Cs. (2000): Munkanélküliség a vidéki Magyarországon Területi Statisztik.a 40 (1): 55-68.

CAlmfors, L.-FORSLUnd, A.-HemströM, M. (2002): Does active labour market policy work? Lessons from the Swedish experiences Institute for Labour Market Policy Evaluation, Working paper 2002: 4, Stockholm.

Cirfusz, M. (2015): A közfoglalkoztatás térbeli egyenlőtlenségei FAZEKAS, K.-VARGA, J. (szerk.): Munkaeröpiaci tükör pp. 126-138., MTA KRTK Közgazdaság-tudományi Intézet, Budapest.

Cseres-Gergely, Zs.-Molnár, Gy. (2014): Közmunka, segélyezés, elsődleges és másodlagos munkaerő-piac In: TÁRKI: Társadalmi riport, 2014 pp. 204-225., Budapest.

CsobA, J. (2010a): A tisz̨tes munka. A teljes foglalkoztatás: a 21. század esélye vagy utópia? L'Harmattan, Budapest.

CsoBA, J. (2010b): A közfoglalkoztatás régi-új rendszere. Útközben az „Út a munkához” program Esély 2010/1: 4-24.

DAX, T. (1996): Defining rural areas: International comparisons and the OECD indicators Rural Society 6 (3): 3-18. https://doi.org/10.5172/rsj.6.3.3

Regional Statistics, Vol. 8. No. 2. 2018: 109-134; DOI: 10.15196/RS080210 
FALuvÉGi, A.-TipolD, F. (2012): A társadalmi, gazdasági és infrastrukturális szempontból elmaradott, illetve az országos átlagot jelentősen meghaladó munkanélküliséggel sújtott települések Területi Statisztika 52 (3): 278-290.

FARKAS, J. Zs.-KOVÁCS, A. D. (2018): Kritikai észrevételek a magyar vidékfejlesztésről a vidékföldrajz szempontjából Területi Statisztika 58 (1): 57-83. https://doi.org/10.15196/TS580103

JÁSZ, E.-KÓTI, T.-PÁSZTOR, I. Z. (2018): A romák társadalmi integrációjának kulcsterületei a Baktalórántházai járás példáján In: PÉNZES, J. Falu-város-periféria: határon innen és túlpp. 108-115. DIDAKT Kft, Debrecen.

KÁLmÁN, J. (2015): A közfoglalkoztatási programok háttere és nemzetközi tapasztalatai In: BlASKÓ, Zs.-FAZEKAS, K.: Munkaerö-piaci tükör pp. 42-58., MTA KRTK, Budapest.

KÓTI, T. (2016): Development of Human Resources in the Hungarian - Romanian Border Region with Special Regard to the Social and Economic Integration of the Roma Population Eurolimes 22: 53-62.

LÁsZLÓ, GY. (2016): A hátrányos helyzetűek foglalkoztatási nehézségei Opus et educatio 3 (3): 264-276.

MARDSEN, T. (1998): New rural territories: regulating the differentiated rural space Journal of Rural Studies 14 (1): 107-117. https://doi.org/10.1016/S0743-0167(97)00041-7

Messing, V. (2012): Kettévágott munkapiac, szétforgácsolt társadalom - Avagy hogyan dezintegrálják a magyar munkaerőpiacot és a társadalmat az állami foglalkoztatáspolitikai beavatkozások, különös tekintettel a közfoglalkoztatási programokra In: KovÁCH, I.-DupCSIK, Cs.-P. TÓTH, T.-TAKÁCS, J. (szerk.): Társadalmi integráció a jelenkori Magyarországon pp. 204-220., MTA TK Szociológiai Intézet - Argumentum, Budapest.

Nemes Nagy, J. (2009): Terek, helyek régiók. A regionális tudomány alapjai Akadémiai Kiadó, Budapest.

PÉNZES, J. (2011): A jövedelmi szempontból elmaradott települések területi átrendeződése a rendszerváltás után Földrajzi Közlemények 135 (1): 59-69.

PÉNZES, J. (2014): Periferikus térségek lehatárolása Magyarországon - módszertani és területi sajátosságok In: NAGY, E.-NAGY, G. (szerk.): Polarizáció-Függöség-Krizis - Eltérö térbeli válaszok pp. 163-175. , MTA RKK, Békéscsaba.

PÉNZES, J. (2015): A kedvezményezett térségek lehatárolásának aktuális kérdései Terïleti Statisqutika 55 (3): 206-232.

Perger, É.-FArKAs, J. Zs.-KovÁCs, A. D. (2016): Delimitation and classification of rural areas in Hungary Romanian Review Of Regional Studies 12 (1): 39-50.

Pospech, P.-DeLín, M.-SPEŠnÁ, D. (2009): Quality of life in Czech rural areas Agricultural Economics 55 (6): 284-295.

Pospech, P.-Kulcsár, L. J. (2016): Rural Sociology and Sociological Theory Sociální studia / Social Studies 13 (2): 5-8.

RAY, C. (1998): Culture, intellectual property and territorial rural development Sociologia Ruralis 38 (1): 3-20. https://doi.org/10.1111/1467-9523.00060

Regional Statistics, Vol. 8. No. 2. 2018: 109-134; DOI: 10.15196/RS080210 
SHuCKSMITH, M. (2010): Disintigrated rural development? Neo-endogenous rural development, planning and place-shaping in diffused power contexts Sociologia Ruralis 50 (1): 1-14. https://doi.org/10.1111/j.1467-9523.2009.00497.x

SÜLI-ZAKAR, I. (2009): The Role of the Euroregions and Eurometropolises in the Etheralization of the Borders in the Eastern Periphery of the European Union EUROLIMES Europe and the Neighbourhood 7: 139-147.

TÉsits, R.-AlPEK, B. L. (2014a): Területi és strukturális jellegzetességek - A közfoglalkoztatás területileg eltérő lehetőségei Magyarországon (1.). Szociálpedagógia 2 (1-2): 45-60.

TÉsITS, R.-AlPEK, B. L. (2014b): Változó funkciók, célok és fejlesztési lehetőségek: A közfoglalkoztatás területileg eltérő lehetőségei Magyarországon (2.) Szociálpedagógia 2 (3-4): 84-96.

TÉsITS, R.-ALPEK, B. L. (2015): A közfoglalkoztatásban részt vevők esélyei és preferenciái: A közfoglalkoztatás területileg eltérő lehetőségei Magyarországon (3.) Szociálpedagógia 3 (1-2): 110-115.

TÉsITS, R.-AlPEK, B. L. (2017): Social Innovations for the Disadvantaged Rural Regions: Hungarian Experiences of the New Type Social Cooperatives Eastern European Countryside 23 (1): 25-40. https://doi.org/10.1515/eec-2017-0002

TóTH, G.-NAGY, Z. (2014): Same or different development paths? A comparative study of the large cities and regions in Hungary Regional Statistics 4 (1): 100-119. http://dx.doi.org/10.15196/RS04107

VÁRADI, M. (2010): A közfoglalkoztatás útjai és útvesztői egy aprófalvas kistérségben Esély 2010/1: 79-100.

VÁRADI, M. (2016): Értékteremtő közfoglalkoztatás a periférikus vidéki terekben Esély 2016/1: 30-56.

VIDA, A.-ViRÁG, T. (2010): Közmunka és napszám. Foglalkoztatás és szociális helyzet DélBékésben Esély 2010/1: 101-118.

\section{Internet references}

105/2015. (IV.23) Kormányrendelet a kedvezményezett települések besorolásáról és a besorolás feltételrendszeréről.

https:// net.jogtar.hu/jogszabaly?docid=a1500105.kor

https://nfsz.munka.hu/Lapok/full_afsz_kozos_statisztika/full_afsz_eves_reszletes/content / full_afsz_eves_2011.pdf

Regional Statistics, Vol. 8. No. 2. 2018: 109-134; DOI: 10.15196/RS080210 